\title{
STRATEGI PENGEMBANGAN PARIWISATA LOKAL
}

\author{
Ade Irma Suryani \\ Program Studi Pendidikan Geografi STKIP PGRI Sumatera Barat \\ adeirmasuryani610@yahoo.com
}

\begin{abstract}
Development of the tourism sector is expected to provide benefits to the community, because the tourism sector is one of the sectors of economic development. Tourism activity is one of the non-oil sector is expected to provide a substantial contribution to the economy Negara.Strategis pengebangan tourism in rural areas, namely by taking into account the advice and the existing infrastructure and the application of the stepping tourism. Tourism facilities can be divided into three parts, namely the principal means of tourism, tourism complementary means and means of supporting tourism. Infrastructure is divided into two parts, namely economic infrastructure and social infrastructure. And subsequent application of Sapta charm on attractions, Sapta charm which contains seven elements that define a good image of the attraction yaitunya: Safe, Orderly, Clean, Cool, Beautiful, and Suave and memories, his presence is very deeply felt important and it was time needed and not only as a basic requirement of tourists, but also as a measure to improve the quality of tourism. Pelaksananaan stepping is at the core of the program in improving the community and tourism awareness is a requirement in tourism development efforts towards the better.
\end{abstract}

Abstrak

Pembangunan bidang pariwisata diharapkan dapat memberikan manfaat bagi masyarakat, karena sektor pariwisata merupakan salah satu sektor pembangunan di bidang ekonomi. Kegiatan pariwisata merupakan salah satu sektor non migas yang diharapkan memberikan kontribusi yang cukup besar terhadap perekonomian Negara.Strategis pengebangan pariwisata pada daerah perdesaan yaitu dengan memperhatikan saran dan prasarana yang ada dan penerapan sapta pesona pariwisata. Sarana kepariwisataan dapat dibagi kedalam tiga bagian yaitu sarana pokok kepariwisataan, sarana pelengkap kepariwisataan dan sarana penunjang kepariwisataan. Prasarana di bagi menjadi 2 bagian yaitu prasarana perekonomian dan prasarana sosial. Dan selanjutnya penerapan Sapta pesona pada objek wisata,Sapta pesona yang mengandung tujuh unsur yang menentukan citra baik terhadap objek wisata yaitunya: Aman, Tertib, Bersih, Sejuk, Indah, dan Ramah tamah serta kenangan, kehadirannya memang sangat begitu terasa penting dan sudah saatnya dibutuhkan, bukan hanya sebagai kebutuhan pokok wisatawan, tetapi juga sebagai tolak ukur dalam meningkatkan kualitas pariwisata. Pelaksananaan sapta pesona merupakan inti dari program dalam meningkatkan sadar wisata masyarakat dan merupakan syarat dalam usaha pengembangan pariwisata kearah yang lebih baik.

\section{PENDAHULUAN}

Indonesia sebagai negara dengan ribuan pulau, beraneka keindahan alamnya dan penduduknya yang terdiri dari ratusan suku bangsa, sesungguhnya memiliki potensi wisata alam, sosial dan budaya yang besar. Potensi dan sumber daya alam yang ada dapat dikembangkan menjadi objek wisata yang menarik. Sebagian besar sumber daya alam tersebut telah dimanfaatkan dan dikembangkan menjadi beberapa objek wisata. Mengingat daya tarik utama wisatawan yang berkunjung ke Indonesia adalah karena keindahan alam dan kekayaan seni budayanya, maka tidak heran jika potensi ini menarik untuk dikembangkan (Pendit, 2002: 66). 
Indonesia memiliki banyak potensi dan sumber daya alam yang belum dikembangkan secara maksimal, termasuk didalamnya di sektor pariwisata. Pembangunan bidang pariwisata diharapkan dapat memberikan manfaat bagi masyarakat, karena sektor pariwisata merupakan salah satu sektor pembangunan di bidang ekonomi. Kegiatan pariwisata merupakan salah satu sektor non migas yang diharapkan memberikan kontribusi yang cukup besar terhadap perekonomian negara.

Kekayaan potensi dan sumber daya alam Indonesia membuka peluang bagi perkembangan pariwisata di Indonesia. Adanya kemajuan teknologi dan juga akibat urbanisasi yang besar, menarik kaum urban menuju pusat-pusat kota untuk mencari nafkah. Akibatnya, banyak orang kota yang terlibat dalam suasana tegang atau mengalami stres. Salah satu pelariannya adalah melakukan rekreasi atau berlibur di tempat-tempat wisata.

Provinsi Sumatera Barat merupakan salah satu potensi unggulan dalam sektor pariwisata, yang umumnya berupa wisata alam, wisata budaya, wisata pantai, wisata danau, dan wisata agro. Dilihat dari daerah yang menjadi tujuan wisata maka Provinsi Sumatera Barat menempati urutan ketiga setelah Provinsi Sumatera Utara dan Provinsi Riau.

\section{PEMBAHASAN}

\section{Pengertian Periwisata}

Menurut Bakaruddin (2008:17) pariwisata adalah suatu perjalanan yang dilakukan oleh seseorang maupun berkelompok untuk sementara waktu, dari suatu tempat ke tempat lain, dengan maksud bukan untuk berusaha dan mencari nafkah di tempat yang dikunjungi, akan tetapi semata-mata untuk menikmati perjalanan tersebut guna pertamasyaan dan rekreasi atau untuk memenuhi keinginan yang beranekaragaman.

Pariwisata berasal dari bahasa sanskerta yang terdiri dari dua suku kata, yaitu "pari" bararti penuh, sedangkan "wisata" artinya perjalanan. Sehingga secara keseluruhan pariwisata diartikan sebagai segala fenomena atau gejala dan hubungan yang ditimbulkan oleh perjalanan atau persinggahan yang dilakukan oleh seseorang untuk berbagai tujuan. Secara etimologis pariwisata terdiri dari dua suku kata yaitu "pari” dan "wisata", pari berarti banyak, berkali-kali, berulang-ulang, sedangkan wisata berarti perjalanan atau berpergian, jadi 
pariwisata adalah perjalanan yang dilakukan berkali-kali atau berulang-ulang dari suatu tempat ke tempat lain

Pengertian lainnya tentang pariwisata adalah, suatu perjalanan yang dilakukan untuk sementara waktu yang diselenggarakan dari suatu tempat ke tempat lain, dengan maksud bukan untuk berusaha (business) atau untuk mencari nafkah di tempat yang dikunjungi, tetapi semata-mata untuk menikmati perjalanan tersebut guna bertamasya dan rekreasi atau untuk memenuhi keinginan yang beraneka ragam (Yoeti, 1996: 118).

Upaya pembangunan sektor pariwisata melibatkan seluruh masyarakat, disamping penyelenggara Negara dan swasta. Meskipun sudah banyak pelaksanaan dan upaya pemerintah dalam mengembangkan pariwisata tersebut. Pemerintah dalam hal ini sangat tergantung dari dukungan masyarakat dan swasta. Ini berarti untuk tercapainya keberhasilan pemerintah dalam melaksanakan pembangunan, perlu adanya dukungan kesadaran dedikasi serta loyalitas dari segenap masyarakat.

\section{Strategi pengebangan Potensi pariwisata}

Modal pariwisata perlu dimanfaatkan dalam pengembangan dan meningkatkan mutu daerah tujuan wisata, untuk melaksanakan terciptanya kondisi yang diharapkan dalam mengembangkan pariwisata maka perlu adanya sapta pesona. Sapta pesona adalah kondisi yang harus diwujudkan dalam rangka menarik minat wisatawan berkunjung ke suatu daerah tujuan wisata serta memperoleh kepuasaan atau kunjungannya. Sapta pesona mencakup unsur keamanan, ketertiban, kebersihan, kesejukan, keindahan, keramah- tamah, dan kenangan. Sapta pesona adalah salah satu unsur pokok dalam pengembangan dan peningkatan kepariwisataan pada suatu daerah tujuan wisata.

\section{Penerapan Sarana dan Prasarana pariwisata}

Sarana maupun prasarana kepariwisataan sesungguhnya merupakan "Tourist Supply" yang perlu disiapkan atau disediakan bila hendak mengembangkan industri pariwisata. Prasarana kepariwisataan sama seperti prasarana dalam perekonomian pada umumnya, karena kegiatan kepariwisataan pada hakekatnya tidak lain adalah sektor perekonomian juga. (Yoeti,1996 dalam Maryati 2013). 
Sarana kepariwisataan adalah perusahaan- perusahaan yang memberikan pelayanan kepada wisatawan, baik secara langsung atau tidak langsung dan hidup serta kehidupannya banyak tergantung pada kedatangan wisatawan, sedangkan prasarana kepariwisataan adalah semua fasilitas yang memungkin agar sarana kepariwisataan dapat hidup dan berkembang serta dapat memberikan pelayanan kepada wisatawan yang beraneka ragam.

Sarana kepariwisataan dapat dibagi kedalam tiga bagian yaitu sarana pokok kepariwisataan, sarana pelengkap kepariwisataan dan sarana penunjang kepariwisataan.

1. Sarana pokok kepariwisataan.

Merupakan perusahaan yang hidup dan kehidupannya sangat bergantung pada arus kunjungan wisata misalnya: Travel agen dan Tour operator, perusahaan angkutan wisata hotel, bar dan restoran serta atraksi wisata.

2. Sarana pelengkap kepariwisataan.

Merupakan perusahaan- perusahaan yang menyediakan fasilitas- fasilitas untuk rekreasi sehingga membuat wisatawan dapat lebih lama tinggal pada suatu daerah tujuan wisata.

3. Sarana penunjang kepariwisataan.

Merupakan perusahaan yang menunjang sarana pokok dan sarana pelengkap dan berfungsi tidak hanya membuat wisatawan lebih lama tinggal pada suatu daerah tujuan wisata, tetapi fungsi yang lebih penting adalah agar wisatawan lebih banyak mengeluarkan atau membelanjakan uangnya ditempat yang dikunjungi. Kelompok yang termasuk sarana penunjang ini antara lain: raigt clup, strembaths, dan casinos.

Prasarana di bagi menjadi 2 bagian yaitu prasarana perekonomian dan prasarana sosial.

a. Prasarana perekonomian yang meliputi:

1) Transportasi yaitu pengangkutan dapat membawa para wisatawan dari tempat tinggal menuju daerah lain atau tujuan wisata. Hal ini dapat dilakukan melalui udara, darat, laut yang semuannya ini adalah untuk memperlancar perjalanan.

2) Prasarana komunikasi yaitu berupa: Telepon,telegraf, radio, Tv, surat kabar, handphone dan lainnya, hal ini penting artinya dalam rangka 
memberitahukan kepada keluarga tentang situasi dan kondisi perjalanan serta menunjukkan kepuasaan pribadi sedang mengapa dan dimana sekarang.

3) Utilities yaitu penerangan listrik, persedian air minum, sistem irigasi dan sumber energi. Faktor utilities sangat penting kalau ingin mendirikan hotel, rumah makan dan tempat- tempat lainnya.

4) Sistem perbankan juga diperlukan karena wisatawan asing dengan sangat cepat dan mudah untuk tukar atau mengirimkan uang dari dan ke Negara asalnya.

b. Sarana sosial adalah faktor yang menunjang kemajuan atau menjamin kelangsungan prasarana perekonomian. Hal -hal yang termasuk dalam kelompok ini adalah:

1) Sistem pendidikan yaitu berupa lembaga-lembaga pendidikan yang mengkhususkan dalam bidang kepariwisataan untuk meningkatkan pelayanan wisatawan.

2) Pelayanan kesehatan, terutama disekitar objek wisata dalam rangka mengantisipasi secara cepat bagi wisatawan yang merasa terganggu kesehatannya. Misalnya pada setiap penginapan perlu kerja sama dengan teknis kesehatan kecuali kalau hotel itu berada dalam kota.

3) Keamanan penting artinya bagi wisatawan, jika keamanan tidak terjamin jangan berharap wisatawan akan berkunjung ke daerah tersebut.

4) Goveerment apparatur yaitu berupa petugas yang langsung melayani wisatawan seperti: petugas imigrasi, beacukai, petugas kesehatan, polisi dan petugas- petugas lainnya.

Prasarana dibagi menjadi tiga kelompok yaitu prasarana umum, kebutuhan masyarakat dan prasarana kepariwisataan.

1) Prasarana umum yaitu menyangkut kebutuhan orang banyak yang tujuannya adalah untuk membantu kelancaran roda perekonomian, pembangkitan tenaga listrik, penyediaan sumber air bersih, sistem jaringan jalan raya, sitem irigasi dan telekomunikasi.

2) Kebutuhan masyarakat banyak seperti rumah sakit, kantor pos, apotik, pompa bensin, perbankan, polisi dan lain sebagainnya. 
3) Prasaranan kepariwisataan diantaranya:

a) Receptive Tourist Plant, segala bentuk organisasi yang mengurus dan mempersiapkan kedatangan wisatawan.

b) Residental Tourist Plant, semua fasilitas yang dapat menampung kedatangan wisatawan untuk menginap dan tinggal untuk sementara waktu di daerah tujuan wisata.

c) Reactive and Sportive Plant, yaitu semua fasilitas yang dapat digunakan untuk tujuan rekreasi dan olahraga (Bakaruddin, 2008:97- 102).

\section{Penerapan Sapta Pesona}

Sapta Pesona adalah untuk meningkatkan kesadaran, rasa tanggung jawab segenap lapisan masyarakat, baik pemerintah, swasta maupun masyarakat luas untuk mampu bertindak dan mewujudkannya dalam kehidupan sehari-hari.

Pelaksanaan sapta pesona merupakan inti dari program pemerintah dalam meningkatkan sadar wisata masyarakat dan merupakan dalam meningkatkan sadar wisata masyarakat dan merupakan syarat mutlak dalam usaha pembangunan pariwisata kearah yang lebih mantap oleh karena itu sapta pesona dijadikan program nasional yang bertujuan meningkatkan kesadaran serta tanggung jawab segenap lapisan pemerintah, swasta, dan masyarakat.

Sapta pesona yang mengandung tujuh unsur yang menentukan citra baik terhadap objek wisata yaitunya: Aman, Tertib, Bersih, Sejuk, Indah, dan Ramah tamah serta kenangan, kehadirannya memang sangat begitu terasa penting dan sudah saatnya dibutuhkan, bukan hanya sebagai kebutuhan pokok wisatawan, tetapi juga sebagai tolak ukur dalam meningkatkan kualitas pariwisata. Pelaksananaan sapta pesona merupakan inti dari program dalam meningkatkan sadar wisata masyarakat dan merupakan syarat dalam usaha pengembangan pariwisata kearah yang lebih baik. Sapta pesona sebagai pedoman nasional yang yang memiliki tujuan.

Adapun tujuan sapta pesona yang ditetapkan oleh Dirjen Pariwisata dalam Bakaruddin (2009) ada 7 (tujuh) pesona yaitu:

a. Keamanan

Wisatawan akan senang berkunjung kesuatu tempat apabila merasa aman, tentram, tidak takut, terlindung dan bebas dari: 
1) Tindak kejahatan, kekerasan ancaman, seperti kecopetan, pemerasan penodongan, penipuan dan lain sebagainya.

2) Terserang penyakit menular dan penyakit berbahaya lainya

3) Kecelakaan oleh alat perlengkapan dan fasilitas yang kurang baik, seperti kendaraan, peralatan, untuk makanan dan minuman, lift, alat perlengkapan atau rekreasi atau olahraga.

4) Gangguan oleh masyarakat, antara lain berupa pemaksaan oleh pedagang asongan tangan jahil, ucapan dan tindakan serta perilaku yang tidak bersahabat dan lain sebagainya.

Jadi keamanan yang dimaksudkan suatu kondisi yang memberikan suasana tentram bagi wisatawan, bebas dari rasa takut dan tidak khawatir akan keselamatan jiwa, raga dan harta milik, bebas dari ancaman, gangguan dan tidakan kekerasan.

b. Ketertiban

Kondisi yang tertib merupakan sesuatu yang sangat didambakan oleh setiap orang termaksud wisatawan. Kondisi tersebut tercermin dari suasana yang teratur, rapi dan rancar serta menunjukkan disiplin yang tinggi dalam semua segi kehidupan masyarakat, misalnya:

1) Lalu lintas tertib, teratur dan lancar, alat angkutan datang dan berangkat tepat waktu.

2) Tidak nampak orang yang berdesakan atau berebutan untuk mendapatkan atau membeli sesuatuyang diperlukan.

3) Bangunan, dan lingkungan ditata teratur dan rapi.

4) Pelayananya dilakukan secara baik dan tepat

5) Informasi yang benar dan tidak membingungkan

c. Kebersihan

Bersih merupakan suatu keadaan/kondisi lingkungan yang menampilkan suasana bebas dari kotoran, sampah, limbah, penyakit, dan pencemaran. Wisatawan akan merasa betah dan nyaman bila berada di tempat-tempat yang bersih dan sehat seperti:

1) Lingkungan yang bersih baik dirumah sendiri maupun di tempat-tempat umum, seperti di hotel, restoran, angkutan umum, tempat rekresi, tempat 
buang air besar /kecil bersih dari sampah, kotoran, coret-coret dan sebagainya.

2) Sajian dan makan dan minuman yang bersih dan sehat

3) Penggunaan dan penyediaan alat perlengkapan yang bersih seperti sendok, piring, tempat tidur, alat olahraga dan lain sebagainya.

4) Pakaian dan penampilan petugas bersih, rapi, dan tidak mengeluarkan bau tidak sedap, lain sebagainya.

d. Kesejukan

Lingkungan yang serba hijau, segar, rapi memberikan suasana atau keadaan sejuk, nyaman dan tentram. Kesejukan yang dihendaki tidak saja harus berada di luar ruangan atau bangunan, akan tetapi diluar ruangan, misalnya ruangan kerja /belajar, ruangan makan, ruangan tidur, dan lain sebagainya.

Untuk itu hendaklah kita semua

1) Turut serta aktif memelihara kelestarian lingkungan dan hasil penghijauan yang telah dilakukan masyarakat ataupun oleh pemerintah.

2) Beberapa secara aktif untuk menganjurkan dan mempelopori agar masyarakat setempat melaksanakan kegiatan penghijauan dan memelihara kebersihan, menanam berbagai tanaman di halaman rumah masing-masing baik untuk hiasan maupun tanaman yang bermamfaan bagi rumah tangga, melakukan penanaman pohon/tanaman yang rindang sepanjang jalan dilingkungan masing-masing, di halaman sekolah dan lain sebagainya.

3) Membentuk perkumpulan yang tujuan memelihara kelestarian lingkungan.

4) Menghiasi ruangan belajar/kerja, ruang tamu, ruang tidur, dan tempat lainya dengfan aneka tanamna penghias atau penyejuk.

5) Memprakarsai berbagai kegiatan dan upaya lain yang dapat membuat lingkungan hidup kita menjadi sejuk, bersih, segar dan nyaman.

e. Keindahan

Keadaan atau suasana yang menampilkan lingkungan yang menarik dan sedap di pandang disebut indah. Indah dapat dilihat dari berbagai segi, seperti dari segi tata warna, tata letak, ruang, bentuk ataupun gaya dan gerak yang serasi dan selaras, sehingga memberi kesan yang enak dan cantik untuk dilihat. Indah yang selalu sejalan dengan bersih dan tertib dan tidak terpisahkan dari lingkungan hidup baik berupa ciptaan tuhan yang Maha Esa 
maupun hasil karya manusia.Karna itu kita wajib memilihara lingkungan hidup agar lestari dan dapat di nikmati oleh umat manusia.

f. Keramah-tamah

Ramah tamah merupakan suatu sikap dan perilaku seseorang yang menunjukkan keakraban, sopan, suka, membantu, suka senyum, dan menarik hati. Ramah merupakan watak budaya bangsa Indonesia pada umumnya, yang selalu menghomati tamunya dan dapat menjadi tuan rumah yang baik. Sikap ramah ini merupakan salah satu daya tarik bagi wisatawan dan harus dipelihara secara baik.

\section{g. Kenangan}

Kenangan adalah kesan yang melekat dengan kuat pada ingatan dan perasaan seseorang yang disebabkan oleh pengalaman yang diperolehnya. Kenagan dapat berupa yang indah dan menyenangkan, akan tetapi dapat pula yang tidak menyenangkan. Kenangan yang ingin diwujudkan dalam ingatan dan perasaan wisatawan dari pengalaman berpariwisata di Indonesia, dengan sendirinya adalah yang indah dan menyenangkan, kenagan yang indah ini dapat pula diciptakan antara lain:

1) Akomodasi yang nyaman, bersih dan sehat, pelayanan yang cepat, tepat dan ramah, suasana yang mencerminkan ciri khas daerah dalam bentuk dan gaya bangunan serta dekorasinya.

2) Atraksi seni budaya daerah yang khas dan mempesona baik itu berupa seni tari, seni suara, berbagai macam upacara.

3) Makanan dan minuman khas yang lezat, dengan penampilan dan penyajian yang menarik. Makanan dan minuman ini merupakan salah satu daya tarik yang kuat dapat dijadikan jati diri (identitas) bangas

Cenderamata yang mungil yang mencerminkan cirri-ciri yang khas daerah, bermutu tinggi, mudah dibawa, dan dengan harga yang terjangkau, mempunyai arti tersendiri dan dijadikan bukti atau kenangan dari kunjungan seseorang kesuatu tempat /daerah

\section{KESIMPULAN}

Strategi pengembangan pariwisata pada suatu daerah yang berpotensi untuk meningkatkankan potensi pariwisata pada suatu daerah.

a. Penerapan Sarana dan Prasarana pariwisata. 
Sarana kepariwisataan adalah perusahaan- perusahaan yang memberikan pelayanan kepada wisatawan, baik secara langsung atau tidak langsung dan hidup serta kehidupannya banyak tergantung pada kedatangan wisatawan, sedangkan prasarana kepariwisataan adalah semua fasilitas yang memungkin agar sarana kepariwisataan dapat hidup dan berkembang serta dapat memberikan pelayanan kepada wisatawan yang beraneka ragam. Sarana kepariwisataan dapat dibagi kedalam tiga bagian yaitu sarana pokok kepariwisataan, sarana pelengkap kepariwisataan dan sarana penunjang kepariwisataan.

b. Penerpan Sapta Pesona

Sapta Pesona adalah untuk meningkatkan kesadaran, rasa tanggung jawab segenap lapisan masyarakat, baik pemerintah, swasta maupun masyarakat luas untuk mampu bertindak dan mewujudkannya dalam kehidupan sehari-hari.

Sapta pesona yang mengandung tujuh unsur yang menentukan citra baik terhadap objek wisata yaitunya: Aman, Tertib, Bersih, Sejuk, Indah, dan Ramah tamah serta kenangan, kehadirannya memang sangat begitu terasa penting dan sudah saatnya dibutuhkan, bukan hanya sebagai kebutuhan pokok wisatawan, tetapi juga sebagai tolak ukur dalam meningkatkan kualitas pariwisata. Pelaksananaan sapta pesona merupakan inti dari program dalam meningkatkan sadar wisata masyarakat dan merupakan syarat dalam usaha pengembangan pariwisata kearah yang lebih baik. Sapta pesona sebagai pedoman nasional yang yang memiliki tujuan.

\section{DAFTAR PUSTAKA}

Bakruddin. 1990.Pengembangan Objek-objek Wisata Alam dan Permasalahannya di Kota Padang. Padang: HIPS IKIP Padang.

Bakarudin. 2009. Perkembangan Permasalahan Kepariwisataan. Padang: UNP press.

http://www.pariamankota.go.id.

Kadhyat, H. 1992.Sejarah Pariwisata dan Perkembangan di Indonesia. Jakarta: Gramedia Widiasarana Indonesia. 
